UDC 342.9

DOI https://doi.org/10.32782/2524-0374/2020-4/53

\title{
ADMINISTRATIVE AND LEGAL QUALIFICATIONS IN DOMESTIC THEORY OF ADMINISTRATIVE LAW
}

\section{АДМІНІСТРАТИВНО-ПРАВОВА КВАЛІФІКАЦІЯ У ВІТЧИЗНЯНІЙ ТЕОРІЇ АДМІНІСТРАТИВНОГО ПРАВА}

\author{
Timashov V.O., Doctor of Law, \\ Professor at the Department of Administrative, Financial and Information Law \\ Kyiv National University of Trade and Economics
}

Oliinyk O.V., Doctor of Law,
Professor at the Department of Legal Security of Business Kyiv National University of Trade and Economics

Through some recent years the problems on defining the concept of "administrative and legal qualifications" have not been studied almost at all. Basically, the above-mentioned topic has been investigated within the aspect of criminal law qualification, and from the standpoint of the theory of law; so, it needs further scientific research and development. With regards to the theory of administrative law, the uncertainty of administrative and legal qualification being juridical institution is the main problem for scholars up to date. Nowadays it can be argued that there is no legitimately justified definition of the "administrative and legal qualifications", and there is no single scientific approach to this concept.

The concept of administrative and legal qualification is used in literature, but it is not defined specifically. The main attention of leading domestic lawyers is traditionally focused on the criminal law aspect of juridical qualification.

The importance of thorough study in the field of such an extraordinary legal reality phenomenon, taking into account administrative and legal qualification (qualification of administrative offense) investigation in juristical literature, is quite obvious. Also, this does not seem to be accidental; evidently, it goes without saying, that there can be no argument or discussion on systematic and error-free application of administrative delict rules taking up no development for perfect doctrinal and legal principles assessing qualifications as the concept under study.

The qualification of administrative offense is quite complex cognitive process. To qualify illegal act of an authorized person often faces a number of problems like the differentiation of peculiar misconducting activity from other kinds of misdemeanor or offense (crimes, civil delicts, etc.), the distinguishing of inter-related administrative offenses; the presence of competition between several administratively delict norms; the presence of administratively delict immunity (i. e., circumstances that exclude liability for administrative misconduct), etc.

The solution of the outlined tasks depends on many factors, that are as follows: the level of professional training of the subjects of administrative jurisdiction, the perfection of equipment used when developing drafts on administratively delict legislation, the existence of clear and accurate practical recommendations. It is significant to notice that none of these factors is possible without scientific solution on current issues of administrative and legal qualifications.

General theoretical aspects of qualification are essential attribute of modern juridical education. The doctrinal provisions of the administrative and legal qualification must be obligatory taken into account when developing administratively delict norms. Designing effective practical recommendations always requires from the author (authors) clear understanding of the legal and psychological nature of the qualification, its content, structure and objective grounds. Therefore, from the point of view of studying regularity, law enforcement and rule-making, the significance of the theory of qualification is just impossible to overestimate.

Key words: administrative-legal qualification, qualification, administrative responsibility, administrative misdemeanor, qualification of administrative misdemeanors, subject of administrative offense.

Проблеми визначення поняття «адміністративно-правової кваліфікації» останнім часом майже не досліджуються. В основному вищевказана тематика досліджується в аспекті кримінально-правової кваліфікації та з позицій теорії права, але потребує подальшого розвитку. У теорії адміністративного права основною проблемою залишається невизначеність адміністративно-правової кваліфікації як правового інституту. Сьогодні можна стверджувати, що немає законодавчого визначення «адміністративно-правової кваліфікації», а також щодо цього поняття відсутній єдиний науковий підхід.

Поняття адміністративно-правової кваліфікації у літературі використовується, але спеціально не визначається. Основна увага провідних вітчизняних правників традиційно прикута до кримінально-правового аспекту юридичної кваліфікації.

У статті зазначається про важливість ґрунтовного вивчення такого непересічного феномену правової дійсності у юридичній літературі, як адміністративно-правова кваліфікація (кваліфікація адміністративного проступку). I це не випадково, адже без вироблення досконалих доктринальних і правових засад кваліфікації не може бути й мови про системне та безпомилкове застосування адміністративно-деліктних норм.

Кваліфікація адміністративного проступку - достатньо складний пізнавальний процес. Кваліфікація протиправного діяння уповноваженої особи часто-густо стикається з низкою проблем, як-то: відмежування діяння від інших правопорушень (злочинів, цивільних деліктів); розмежування суміжних складів адміністративних проступків; наявність конкуренції декількох адміністративно-деліктних норм; наявність адміністративно-деліктних імунітетів (тобто обставин, що виключають відповідальність за адміністративні проступки) тощо.

Вирішення окреслених задач залежить від багатьох чинників: рівня профресійної підготовки суб'єктів адміністративної юрисдикції, досконалості техніки, використаної під час розробки актів адміністративно-деліктного законодавства, існування чітких практичних рекомендацій. Показово, що жоден з цих чинників неможливий без наукового вирішення актуальних питань адміністративно-правової кваліфікації.

Загальнотеоретичні аспекти кваліфікації є неодмінним атрибутом сучасної юридичної освіти. Доктринальні положення адміністративно-правової кваліфікації обов'язково враховуються під час розробки адміністративно-деліктних норм. Конструювання ефрективних практичних рекомендацій завжди потребує від автора (авторів) чіткого розуміння юридичної і психологічної природи кваліфрікації, її змісту, структури та об'єктивних підстав. Відтак з погляду науки, що вивчає закономірності, правозастосування та нормотворення, значущість теорії кваліфікації переоцінити просто неможливо.

Ключові слова: адміністративно-правова кваліфікація, кваліфікація, адміністративна відповідальність, адміністративний проступок, кваліфікація адміністративних проступків, суб'єкт адміністративного проступку.

Presentation of the main material. Issues concerning definitions of the concept of "administrative and legal qualifications" have not been studied thoroughly of late. Basically, the above-mentioned topics are having been investigated through the aspect of criminal law qualification, and from the standpoint of the theory of law, which needs further 
research and development. As for the theory of administrative law, the main problem that still remains indistinct, is the uncertainty of administrative and legal qualification as the legal institution. Today it can be argued that there is no legislative definition for the "administrative and legal qualifications", and there is no single scientific approach to this concept.

The concept of administrative and legal qualification is used in literature, but it is not defined specifically. The main attention of leading domestic lawyers is traditionally focused on the criminal law aspect of juridical qualification. The qualification of crimes has been and still remains the subject of active scientific investigations, heated by immense discussion and debate. Its content is revealed in dozens of monographs, doctoral and candidate dissertations, text-books and scientific articles. The meaningful content in the field of criminal law being the "golden mean" of the issue on criminal liability cannot be thought over other way than within unbreakable connection to the qualification of crimes.

Thus, on the contrary to the criminal law sphere, which focuses purely on the regulation of delict relationships, administrative law has much wider range of assignments, they are: the provision of administrative services, public administration, administrative justice, and others. Therefore, liability for administrative misconduct is not a central axis in the field of administrative law, and the related issues (including issues of administrative and legal qualification) are not considered as preferable ones.

Basing on the mentioned above, we may affirm that the reason for the permanent lack of attention to the relevant issues is the hyperbolizing idea of the comparatively insignificant qualification of some administrative misdemeanor, that is their obviousness and simplicity of juridical content. Sometimes there can be payed attention onto the issue of administrative and legal qualifications which are not worthy for fundamental study because the administrative misconduct is quite primitive in its nature, and its juridical assessment does not make any significant complications.

In our opinion, it is difficult to agree with this point of view. In fact, social danger of some particular administrative misdemeanor is always less than social threat of a particular offense (crime). When comparing quantitative parameters of some crimes and administrative delicts, the picture is sometimes diametrically opposed.

For example, in present day Ukraine there are more than six thousand cases annually recorded on violations established by the Article \# 41, part 1 of the Code of Ukraine on Administrative Offenses, like payments concerning pensions, scholarships, salaries and wages deadlines, and also underpayment, meaning their not full volumes given [1], and only a few crimes are consolidated in the Criminal Code of Ukraine and provided by the Article \# 175 of the Criminal Code of Ukraine as for unjustified and intentional non-payment of wages, scholarships, pensions or other statutory payments. Which of these two phenomena (administrative or criminal delict on labor protection) more relevant for society in the whole is a debatable question.

The other important and debatable issue is the question on the simplicity of juridical qualification of administrative misdemeanors consolidated in the Article \# 121 and \# 122 of the Code of Ukraine on Administrative Offenses in comparison with the offenses (crimes) specified in the Article \# 286 of the Criminal Code of Ukraine. Obviously, the vast majority of features of legal composition of administrative and criminal violations of traffic rules (in particular, the object, the subject, the subjective side, the nature of the illegal act) are absolutely identical.

The main difference between mentioned administrative offenses is stated above, and the nature of misdemeanors and crimes is characterized by the upcoming harmful material consequences to society. Thus, from the point of view of legal complexity, the qualification of both types of delicts is of little difference. Moreover, some administrative offenses significantly outweigh the majority of crimes in terms of their complexity of the legal content. For example, the administrative and legal qualification in abuses of monopoly position on the market (Article 166-1 of the Code of Ukraine on Administrative Offenses) requires from the authorized entity not just applying to a number of legal acts and documents (like the Commercial Code to the Decisions of the Antimonopoly Committee of Ukraine), but also to conduct complex economic and mathematical calculations (in particular, when determining the share of some particular business entity/entities on the market).

Therefore, comparative insignificance of some administrative misdemeanors does not diminish the importance of the phenomenon of administrative and legal qualifications and should not be reflected beneath the depth of its scientific development.

The fact remains as it is that through the period of 1996-2010 in Ukrainian jurisprudence literature appeared insignificantly small number of scientific papers on the theory of administrative and legal qualifications. In 1996 O.I. Ostapenko's Doctor's Degree dissertation "Administrative Delict" was published [2]. In this work (or rather, in one of its chapters) the author pays attention to such important issues like defining the concept of administrative and legal qualifications, clarifying its content and structure, also defining its prerequisites and basic determinants. In the middle of 2000 -th professor T. Gurzhii, defined the concept of administrative and legal qualification, also clarified its content and structure, as well as its prerequisites and basic determinants [3-7]. Subsequently, the main provisions of T. Gurzhii's works found practical implementation within the development of draft laws of Ukraine, draft decisions of the National Security and Defense Council of Ukraine, drafts of Orders of the Ministry of Infrastructure of Ukraine, the Ministry of Internal Affairs of Ukraine and other central executive bodies. In addition, they are widely used through educational process in a number of Establishments of Higher Education of Ukraine.

Confirming the importance of provisions, formulated by Professor O.I. Ostapenko, the theoretical statements on administrative and legal qualifications can be acknowledged as follows:

First, both from psychological and legal point of view, the qualification of administrative offense is a dualistic phenomenon. In psychological aspect, the dual essence of qualification is manifested in the fact that it is simultaneously: a) the process of comprehension to legal essence of an illegal act committed in real life; b) the final judgment (inference) resulting the process of cognition. As a legal phenomenon, qualification it is also an inseparable unity of two points: a) the process of comparison between the signs of actual encroachment and the juridical norm; b) juridical conclusion consolidated in procedural documents [2, p. 208-210].

Second, based on the previous provision, O.I. Ostapenko defines the concept of administrative and legal qualification as "the establishment and procedural consolidation of exact correspondence of signs concerning illegal actions or inaction committed by the person featuring structure of the delict, provided by the administrative legislation" $[2$, p. 40$]$.

It should be noted that this definition has repeatedly been criticized from the side of scientific researchers in this sphere.

However, T.O. Gurzhii questioned the thesis of consolidation the content of the delict into administrative law, which clearly follows from the above-given definition. According to the opinion of this scholar, administrative law provides for the misdemeanor itself, but not its content (composition) being an abstract model, which compares the signs of actual encroachment and signs of misconduct, consolidated within the administratively delict norm/norms. According to the author's opinion, the content of administrative offense is just a theoretical construction, meaning, that "...the law does 
not know, and which any author understands and interprets in his own way" [3, p. 29]. Therefore, when talking about qualification, it should be borne in mind that it is necessary to establish firm correspondence between the actual features of the act and the normative features of an administrative offense (and not of its content or composition), on which the author insists [5, p. 219; 6, p. 13; 7, p. 29].

Another administrative law researcher - O.M. Storozhenko - emphasizes on the inexpediency of using the term "compliance" in the definition of the term "administrative and legal qualification". In her reasoning, the author based on the experience of the Humanities and the Natural Sciences (Chemistry, Mathematics, Biology, Physics), where compliance is understood as functional connection of conditions, parties, objects [8, p. 11-16]. At the same time the author also argues that in relation to compliance there are all the signs of the factual action and the signs of misdemeanor consolidated in the administratively delict code of regulations. For example, both the purpose of the misdemeanor and its harmful consequences functionally correspond to certain forms of guilt. The goal always indicates the presence of direct intention; and the commission of administrative delicts with formal contents (without harmful consequences occurrences) is possible only in the form of direct intent or unlawful negligence. With this understanding of the compliance, as O. M. Storozhenko states, the reference to it when defining the concept of qualification seems not quite appropriate, because "qualification is not a statement of all the multifaceted and multidirectional functional links between the actual encroachment and the legal formula of the delict, but also it is the establishment of identity of each feature of the factual action to the corresponding feature of the administrative offense (the real subject - to the normative features of the subject of the offense, the real guilt - to the legislative formula of guilt, etc.) [9, p. 274]". Therefore, in the context of administrative and legal qualifications, we should not talk just about the compliance, but also about the identity of factual and legal signs of the encroachment, as O.M. Storozhenko actually sums up [9, p. 275].

It goes without saying, that the expressed remark has certain scientific value, but, in our opinion, its practical significance is quite conditional. Much more practical significance has another O.M. Storozhenko's detailed specification, which regards to the thesis of comparing the process of qualification of the signs of administratively delict norms and signs of actual actions or inactions. As the author rightly notes, the use of the semantic construction of "actions or inactions" may incorrectly direct the authorized person onto the fact that in the course of qualification the signs of actual encroachment should be "tried" only on for the signs of the objective party of administrative delict [9, p. 276]. It seems that in this case it is actually more correct to talk about encroachment in general, but not on the action or inaction.

Paying the tribute to the fact that all the above remarks bear exclusively clarifying nature, they diminish in no way the role of the definition of the concept "administrative and legal qualifications", built by O.I. Ostapenko. This is acknowledged by the critics themselves, who unanimously support the definition of Professor O.I. Ostapenko: "...the most reasonable of those are available in domestic administrative and legal literature" $[2$, p. 44] and "dominating in the theory of administrative law in the whole" [2, p. 31].

It is quite easy to notice, that Professor O.I. Ostapenko considers the procedural consolidation signs of the action compliance to the signs of the misdemeanor as an integral ele- ment of the qualification of an administrative offense, reflected in the content of administratively delict norms. According to the formal-logical rules of division of concepts into classes (types), all features inherent in the general concept and are necessarily included into the content of all its varieties $[2$, p. 32 ; 36]. Therefore, if taking the above definition as the basic one, then according to all logical criteria, the procedural consolidation should be equally inherent in both official and doctrinal qualifications. In fact, this is not the case at all. It is obvious that the procedural legalization of qualification results contradicts the idea of its informality (doctrinaire). Doctrinal qualification is therefore called informal, which is not expressed in official documents. Conversely, the procedural consolidation of qualification directly indicates its official nature.

Despite some logical flaws, the general theoretical significance of the analyzed classification is difficult to overestimate. The fact cannot be refuted, that this classification set the general direction to all further research on the scope of the concept on administrative and legal qualifications.

Third, Professor O.I. Ostapenko also is one of the first scholars who attempts to determine the prerequisites for administrative and legal qualifications. All in all O.I. Ostapenko identifies three prerequisites: 1) comprehensive, complete and objective establishment of all factual circumstances of the case; 2) accurate and reliable determination of the legal significance among all factual circumstances of the committed illegal actions and the identity of the violator; 3 ) the correct choice of administrative law and clarification of its content and meaning [2, p. 210]. Subsequently, the concept under consideration has been repeatedly clarified (to be discussed below), that has not also prevented its general recognition. A vivid evidence of which is the reflection of O.I. Ostapenko's key ideas on to the scientific achievements of the leading scientists of domestic jurisprudence, let's say V.K. Kolpakov and O.I. Kuzmenko [10, p. 8-10].

Fourth, O.I. Ostapenko in his works pays special attention to questions of administrative and legal qualification structure. "Since the qualification of administrative delict is a logical process that takes place over a period of time, it is necessary to determine certain terms that reflect qualitative originality of a particular part of the qualification process" as he emphasizes [2, p. 210, 211]. In author's reasoning, the scholar takes into account differences in understanding the structure of qualifications in administrative and criminal law. If in criminal law the stages of qualification are usually identified with the stages of application to the juridical norm, then administrative law connects them with the stages of the proceedings on the case [2, p. 43].

As it has been already mentioned, the qualification is cognitive process. It is extremely complex, multi-vectoral and being at the same time non-schematic. Within the consciousness of any individual there is no formulation and no way to form an inviolable algorithm for drawing inferences. Some cognitive processes of consciousness occur simultaneously, some are constantly repeated, etc. Thus, the awareness of the general administrative delict of encroachment occurs simultaneously with the statement of the presence of signs of a specific administrative offense in it. During the qualification, the subject may be re-applied to the analysis of the generic features of the delict and then some.

As for the practical aspect of the issue under consideration, often an experienced subject of jurisdiction immediately qualifies the encroachment onto a particular administratively delict norm, bypassing the procedure of its preliminary assessment.

\section{REFERENCES}

1. Кодекс України про адміністративні правопорушення. Відомості Верховної Ради Української РСР. 1984. Дод. до № 51. Ст. 1122.

2. Остапенко О.І. Адміністративна деліктологія : Іис... д-ра юрид. наук : 12.00.07. Київ : УАВС, 1996. 401 с.

3. Гуржій Т.О. Актуальні проблеми державного прогнозування у сфері безпеки дорожнього руху. Проблеми правознавства та правоохоронної діяльності. 2009. № 3. С. 68-73.

4. Гуржій Т.О. Керування автотраспортними засобами : адміністративно-деліктний аспект : монографія. Кіровоград : Полімед-сервіс, 2007. 255 c. 
5. Гуржій Т.О. Логіко-методологічні засади визначення поняття адміністративно-правової кваліфікації. Вісник Української Академії державного управління при Президентові України. 2002. № 4. С. 218-223.

6. Гуржій Т.О. Логіко-фрілософські категорії і класифікація об’єктів адміністративного делікту. Право України. 2003. № 1. С. 13-17.

7. Гуржій Т.О. Місце кваліфікації у процесі правозастосування. Право України. 2006. № 4. С. 29-31.

8. Стороженко О.М. Адміністративно-правова кваліфікація зловживань монопольним (домінуючим) становищем на ринку : Дисертація на здобуття наукового ступеня кандидата юридичних наук : 12.00.07. Київ : ВМУРЛ «Україна», 2008. 183 с.

9. Стороженко О.М. Теоретичні проблеми визначення поняття кваліфікації адміністративного складу / держави та права. Збірник наукових праць. Випуск № 35. 2007. с. р. 270-276.

10. Колпаков В.К., Кузьменко О.В. Адміністративні правопорушення в системі корупційних деліктів. Боротьба з організованою злочинністю та корупцією (теорія та практика). 2002. № 5. с. р. 7-12. 